\title{
INFLUENCE OF Zn AND Pb ON RHIZOPOGON ROSEOLUS MYCELIUM - ENERGY DISPERSION SPECTROSCOPY AND CYTOCHEMICAL INVESTIGATION
}

\author{
KATARZYNA TURNAU ${ }^{1}$, JADWIGA FABER ${ }^{2}$, JEAN DEXHEIMER $^{3}$, BERNARD BOTTON ${ }^{4}$ \\ ${ }^{1}$ Institute of Botany of the Jagiellonian University, \\ ul. Lubicz 46, 31-512 Kraków, Poland \\ ${ }^{2}$ Institute of Zoology of the Jagiellonian University, \\ ul. Ingardena 6, 30-060 Kraków, Poland \\ ${ }^{3}$ Laboratoire de Biologie des Ligneux - Equipe Cytophysiologie des Mycorhizes, \\ Universite H. Poincaré, Nancy I, B.P. No. 239, 54506 Vandoeuvre-les-Nancy, Cedex, France \\ ${ }^{4}$ Laboratoire de Biologie Forestière associé INRA, \\ Universite H. Poincaré, Nancy I, B.P. No. 239, 54506 Vandoeuvre-les-Nancy, Cedex, France
}

(Received: September 10, 1998. Accepted: November 6, 1998)

\begin{abstract}
Mycelium isolated from fruitbodies of Rhizopogon roseolus, collected from calamine wastes in Poland, was cultivated on agar media supplemented with $\mathrm{Zn}$ or $\mathrm{Pb}$ salts. The stimulation of exudate production by the aerial mycelium and the mycelium growing on the surface of the media, accompanied by the change of mycelium pigmentation, was found as a result of $\mathrm{Zn}$ application. The presence of $\mathrm{Pb}$ resulted mainly in the stimulation of crystalloid production on the surface of mycelium, in direct contact with the medium. Exudate droplets formed on the surface of mycelium cultivated on media with and without the $\mathrm{Zn}$ addition, were investigated by means of cytochemical tests (PATAg and Gomori-Swift reaction). In the control media most droplets gave a diffused, positive reaction to both tests. In media supplemented with $\mathrm{Zn}$ salts, besides the droplet-like material described in the control also another kind of exudate was observed. It was characterized by the collar showing a positive Gomori-Swift reaction, while the rest of the exudate had an oily appearance and gave a faint or no reaction to both tests. Comparative research by means of scanning electron microscopy accompanied by energy dispersion spectroscopy, was carried out showing the differences in exudate and in mycelia composition as a result of the $\mathrm{Zn}$ and $\mathrm{Pb}$ presence in the medium.
\end{abstract}

KEY WORDS: ectomycorrhiza, Rhizopogon roseolus, heavy metal sequestration, pigments.

\section{INTRODUCTION}

An investigation on ectomycorrhizas of Rhizopogon roseolus/Pinus sylvestris collected from calamine dumps in Southern Poland has shown the heavy metal filtering effect within the fungal mantle (Turnau et al. 1996). Potentially toxic elements were detected, using electron energy loss spectroscopy (EELS, ESI), mainly in the mantle, and a decreasing gradient of these elements was found from the outer part of the mantle to the inner part of the root. The results indicated that this phenomenon is due to the electron-opaque substance excreted in the region of the mantle and in the extraradical hyphae. In addition, an abundant deposition of crystals containing metals such as $\mathrm{Cd}, \mathrm{Cu}, \mathrm{Zn}$ and $\mathrm{Pb}$, as shown by $\mathrm{X}$-ray microanalysis, was found in the outer layer of the fungal mantle (Turnau et al. 1995). Due to the high complexity of environmental factors on industrial wastes and also the possibility of interactions with other organisms within the mycorrhiza of $R$. roseolus, a full interpretation of data was hard and the need of further investigation concerning pure mycelial culture was highlighted.
The presently reported experiment was designed to distinguish the effects of $\mathrm{Zn}$ and $\mathrm{Pb}$ on the mycelium. The paper reports the results on the element content in Rhizopogon roseolus mycelium, by means of energy dispersion spectroscopy accompanied by a scanning electron microscope. The material for the analysis was lyophilized in liquid nitrogen to overcome the problem of loosing elements during chemical fixation. Additionally, chemically fixed material was observed with TEM. Cytochemical tests, revealing the presence of polysaccharides and proteins rich in cysteine, were carried out to study the nature of the material involved in detoxification.

\section{MATERIALS AND METHODS}

\section{Isolation and identification of mycelium}

Fruitbodies of Rhizopogon roseolus (Corda in Sturm) Th. Fr. were collected from the calamine dumps of Boleslaw near Olkusz (Southern Poland) (Turnau et al. 1996). The mycelium was obtained from fruitbodies which, after peeling the surface layer, were surface sterilized over the flame and split into 
halves. The pieces of the fruitbodies were subsequently localized on the MNM agar medium. The identity of sporocarps, rhizomorphs, mycorrhizas and mycelia of the isolated strains (fresh material) was verified by PCR-RFLP methods (Gardes and Bruns 1991) employing the universal primers ITSI and ITS4 (White et al. 1990), which amplified the ITS regions of rDNA. Forty-four cycles were run at an annealing temperature of $54^{\circ} \mathrm{C}$. The restriction enzymes used were AluI, HaellI, HinfI, HpaII, TaqI purchased from IBM Fermentas (Lithuania). DNA fragments were separated by gel electrophoresis in 0.5x TAE-buffer pH 8.6 (Sambrock et al. 1989). Gels were run for about 0.5 hour at $100 \mathrm{~V}$. Fragment lengths were estimated by comparison to the 100-bp ladder (IBM Fermentas) used as the DNA standard. Data was rounded to the nearest $5 \mathrm{bp}$.

The isolated mycelium was transferred to the MNM agar media, supplemented with 100, 200 and $500 \mathrm{ppm}$ of $\mathrm{Zn}$ or Pb sulfates. The heavy metal salts were mixed with the agar medium after sterilization in order to avoid precipitation.

\section{SEM studies}

Mycelium collected with care to avoid contact with the agar block was lyophilized in liquid nitrogen (tissue dryer EDWARDS ETD4), mounted on carbon stubs and covered with carbon. It was observed with scanning electron microscope JEOL JSM-5400 and analyzed by an energy dispersion spectroscope with a silicon/lithium detector (NORAN). The microscope was operated at 10 or $20 \mathrm{kV}$ and a magnification of 50-100 thousands. The estimated depth of the electron beam penetration was 2-4 $\mu$ m (Monte Carlo Simulation by David C. Joy, version Feb. 1995). Computer analysis was carried out using the Voyager 3.6 program. Analysis of variance (ANOVA, $\alpha=0.05$ ) was used to compare data.

\section{TEM studies}

Mycelium of $R$. roseolus was fixed in $2 \%$ glutaraldehyde/0.2 M Hepes buffer (1:1), postfixed in osmium tetroxide and after dehydration, embedded in Spurrs resin as recommended by Kottke (1991). Semi-thin sections (0.5-1.5 $\mu \mathrm{m}$ thickness) were stained with crystal violet for light microscopy. Ultra-thin sections of 80-120 nm thickness were stained with lead citrate and uranyl acetate and then investigated with a TEM 902, Zeiss.

Both cytochemical tests were carried out on noncontrasted sections of $80-120 \mathrm{~nm}$ thickness, collected on gold grids. For PATAg (periodic acid-thiocarbohydrazide-Ag proteinate test), used to detect polysaccharides (Thiery 1967), the sections were: (1) floated on $1 \%$ periodic acid for $30 \mathrm{~min}$; (2) washed in distilled water; (3) floated on $0.2 \%$ thiocarbohydrazide in $20 \%$ acetic acid for $5 \mathrm{~h}$; (4) immersed in an aqueous solution of acetic acid in decreasing concentrations (20,15, 10, 5\%), twice in each solution for $5 \mathrm{~min}$; (5) washed twice for $10 \mathrm{~min}$ each in distilled water; (6) immersed in $1 \%$ aqueous silver proteinate (in the dark) for $20 \mathrm{~min}$ and (7) washed in distilled water. Controls were performed by replacing the periodic acid treatment with 5-10\% $\mathrm{H}_{2} \mathrm{O}_{2}$ (Hall and Hawes 1991).

The Gomori-Swift reaction (Swift 1968), revealing cystinerich proteins, was performed in the solution obtained by mixing two components just prior to staining. The first one (A) contained $5 \mathrm{ml} \mathrm{5 \%}$ silver nitrate and $100 \mathrm{ml} \mathrm{3 \%}$ hexamethylentetramine. The second (B) was composed of $10 \mathrm{ml}$ $1.44 \%$ boric acid and $100 \mathrm{ml} 1.9 \%$ borax. The final solution was obtained by mixing $25 \mathrm{ml}$ of $\mathrm{A}, 5 \mathrm{ml} \mathrm{B}$ and $25 \mathrm{ml}$ distilled water. Staining was performed for 1.5 or $2 \mathrm{~h}$ at $45^{\circ} \mathrm{C}$ in darkness. The grids were then washed several times in distilled water and dried.

\section{RESULTS}

\section{Identity verification by RFLP studies}

DNA isolated from fruitbodies, rhizomorphs, mycorrhizas and from mycelium isolated from sporocarps, gave an identical pattern of DNA-fragments after digestion with AluI, HaeIII, HinfI, HpaII and TaqI. The total length of undigested ITS 1/4 fragment was $620 \mathrm{bp}$. For AluI the following fragment lengths were found: $400 \mathrm{bp}, 280 \mathrm{bp}$; for HaellI - $660 \mathrm{bp}$, for Hinf - 220 bp and 130 bp, for HpaII - 480 bp and 290 bp, for TaqI $-295 \mathrm{bp}$ and $105 \mathrm{bp}$.

\section{Conventional SEM-observations}

The mycelium of $R$. roseolus cultivated on media without heavy metals was characterised by the formation of dropletlike exudations (Fig. 1). The droplets were not uniformly distributed. Some of the hyphae were very smooth, while the droplets were more common on aerial mycelium where some of the hyphae were sticking together due to presence of the exudates. Some of the droplets were spherical, but in older cultures they formed a solid incrustation (Fig. 2.) of the hyphae (already visible with a light microscope). More regular crystalloids were occasionally observed on the surface of the mycelium growing more closely to the agar. These crystalloids, however, were either in contact with the agar and mycelium or only with the mycelium. The presence of $\mathrm{Zn}$ in media however, while not having much influence on the growth rate (up to $500 \mathrm{ppm}$ of $\mathrm{ZnSO}_{4}$ ), strongly affected the appearance of the mycelium. The production of exudates was significantly increased and smooth mycelia were extremely rare. At the same time crystalloids were absent. On the contrary, a $\mathrm{Pb}$ addition to the media resulted in the stimulation of crystalloid formations on the surface of the mycelia, which were closer to the agar media. Droplet exudations were less abundant than in the control.

\section{TEM observations}

Droplet-like exudates observed on the surface of $R$. roseolus mycelium, cultivated on the agar medium supplemented with $\mathrm{Zn}$ salt or on media without a heavy metal addition were studied using TEM methods. In the control material (without $\mathrm{Zn}$ addition) the droplets were usually smaller and less common. They were characterized by a granular appearance (Fig. 3) and gave a uniform positive PATAg (Fig. 4) and GomoriSwift reaction. These droplets were often visible between hyphae and mostly embedded in polysaccharidous fibrillar seath. In $\mathrm{Zn}$ supplemented media two kinds of droplets have been observed using cytochemical staining. The first kind, usually of much smaller size, was similar to the exudates in the control material. The second kind was less uniform in stainings (Figs 5-10). Already in the conventional sections (Figs 5-6), stained with uranyl acetate and lead citrate, a faint collar was discerned around the droplets. The collar gave an uneven reaction to PATAg test (Figs 7-8), with a slightly stronger staining at the base and hardly any staining on the edge. The whole collar gave a uniform positive Gomori-Swift reaction (Figs 9-10) similar in strength to those revealed within the droplets from the control media. The central part of the exudates from the $\mathrm{Zn}$ media gave a faint or no reaction to both tests and was oily in appearance.

\section{EDS results}

Mycelium cultivated without heavy metals - according to energy dispersion spectroscopy analysis carried out on smooth mycelium, $\mathrm{C}$ and $\mathrm{O}$ (in ratio $2: 1$ ) were the main elements as in all the biological samples. In addition $\mathrm{Na}, \mathrm{S}, \mathrm{K}$ up 

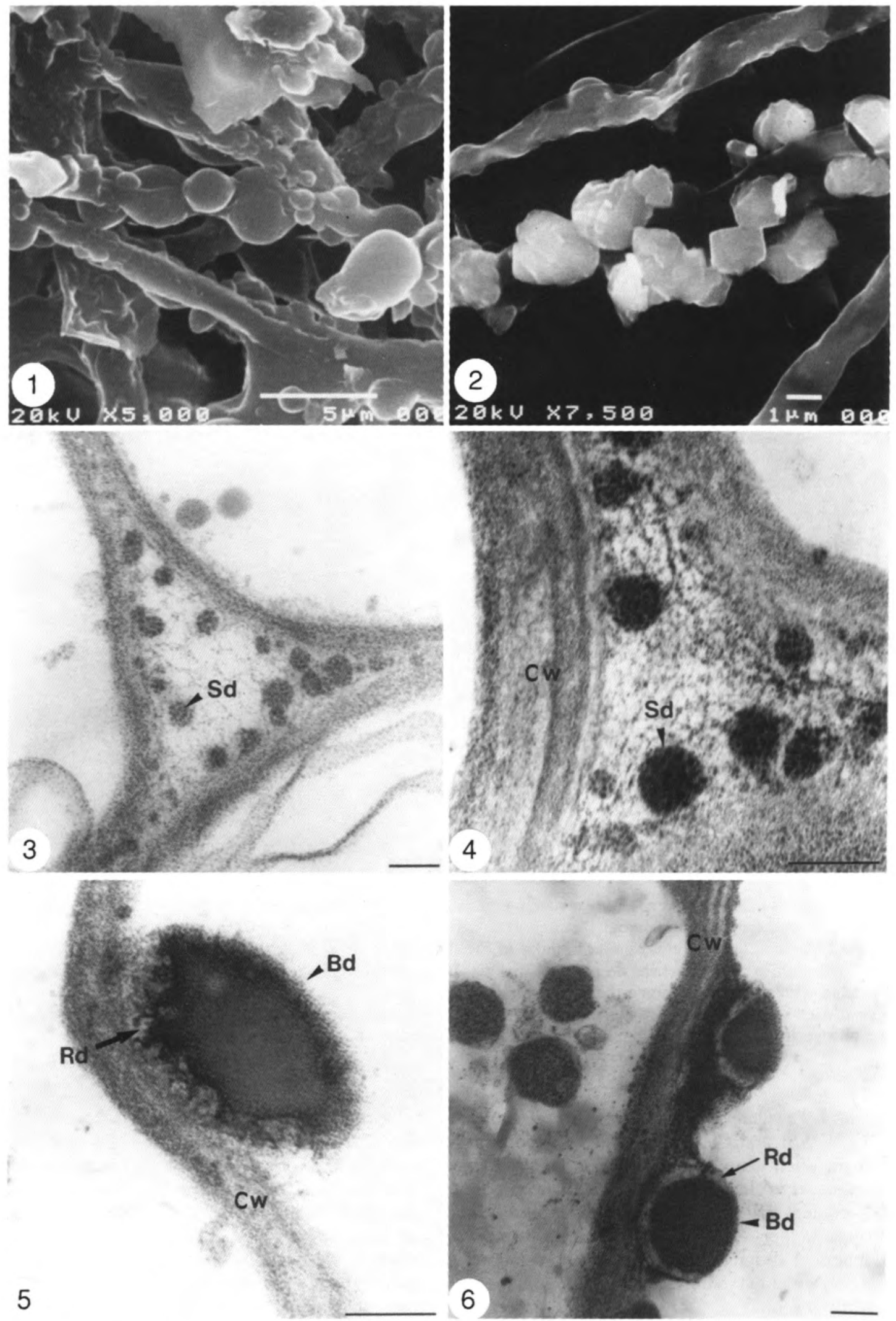

Figs 1-6. Rhizopogon roseolus mycelium

Fig. 1. SEM micrograph of mycelia cultivated on media supplemented with $\mathrm{ZnSO}_{4}$, revealing the abundant production of droplet-like exudates. Fig. 2. SEM micrograph of mycelia cultivated on media with $\mathrm{ZnSO}_{4}$ showing the crystalloids on the surface of the mycelia.

Fig. 3. Conventional TEM micrograph (double stained) revealing the deposition of granular material between hyphae cultivated on the control media (without a heavy metal addition).

Fig. 4. PATAg staining (revealing polysaccharides) of a similar area as in Fig. 3.

Fig 5. Conventional TEM micrograph of big droplet-like material with a ring at the base formed by the mycelia on $\mathrm{Zn}$ supplemented media. Fig. 6. PATAg staining of a similar area as in Fig. $5(b a r=1 \mu \mathrm{m})$. Abbreviations: Bd, big droplet-like deposition on the surface of the mycelium; $\mathrm{Cw}$, cell wall; Ex, material on the surface of the mycelium; Fm, fibrillar material between hyphae; Rd, ring surrounding big droplets; Sd, small droplet-like material; Vd, vacuolar deposition. 

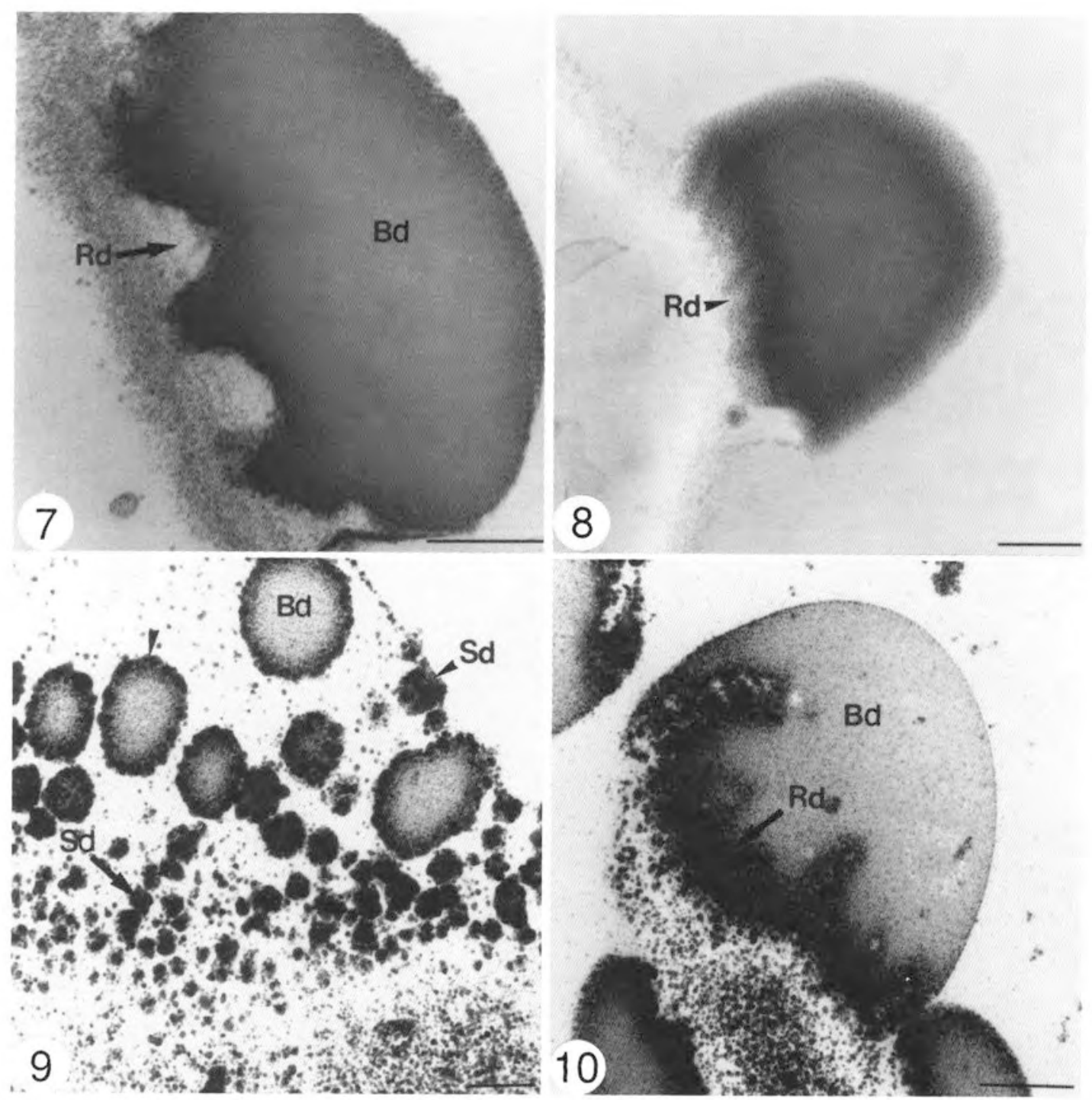

Figs 7-10. TEM micrographs of Rhizopogon roseolus mycelium cultivated on $\mathrm{Zn}$ supplemented media:

Fig. 7. PATAg staining of big, droplet-like material.

Fig. 8. Control for PATAg staining of an area similar to those in Fig. 7.

Fig. 9. Gomori-Swift reaction in an area where droplet-like material is formed, revealing two types of droplets, one uniformly stained (small depositions) and another with a ring surrounding the oily material.

Fig. 10. Gomori-Swift reaction of a big droplet-like material with a clearly stained ring; bar = $1 \mu \mathrm{m}$. Abbreviations: Bd, big droplet-like deposition on the surface of mycelium; Rd, ring surrounding big droplet-like material; Sd, small droplet-like material;

to $1 \%$ and $\mathrm{P}$ up to $1.9 \%$ were found. There were also elements such as $\mathrm{Mg}, \mathrm{Cl}, \mathrm{Si}$ and $\mathrm{Ca}$, the content of which did not exceed $0.3 \%$ in each case. In comparison to smooth mycelium the droplets were characterized by a similar ratio of $\mathrm{C}$ and $\mathrm{O}$ and an $\mathrm{S}$ content that was four times lower and a $\mathrm{Ca}$ level over four times higher. No significant differences were found between spherical droplets and irregular incrustations in older cultures. Polygonal crystalloids contained much more $\mathrm{Ca}$ (up to $6 \%$ ) while the ratio of $\mathrm{C}: \mathrm{O}$ was close to $1: 1$. The content of $\mathrm{S}$ was two times lower than in the smooth mycelium but two times higher than in the droplet exudates. At the same time the content of P was usually $20 \%$ higher than in the smooth mycelium and in the droplets.

Mycelium cultivated on $\mathrm{Zn}$ supplemented media - the addition of $\mathrm{Zn}$ to the media resulted in a decrease of $\mathrm{Mg}$ (three times), P, S and $\mathrm{Cl}$ (two times) in smooth mycelium. Strong changes were noted in the element content of the pigment. In comparison with the smooth mycelium of the same cultures, the pigment contained three times more $\mathrm{S}$ and about twice the level of $\mathrm{Na}$. The level of $\mathrm{P}$ ranged from $0.4-1.2 \%$ dry weight and had a tendency to increase with the increase in the $\mathrm{Zn}$ level. In comparison with the pigment from the control media (no heavy metals), pigment from the $\mathrm{Zn}$ supplemented media contained about six times more $\mathrm{S}$ while the level of $\mathrm{Ca}$ was six times lower (Fig. 11). Zn content which ranged from 1.5 to $4 \% \mathrm{~d}$. w. was found in the whole mycelium with a tendency to be lower in the aerial mycelium than in the mycelium growing close to the medium.

Mycelium cultivated on $\mathrm{Pb}$ supplemented media - the addition of $\mathrm{Pb}$ to the media resulted in an even distribution of $\mathrm{S}$ in smooth mycelium, droplets and crystalloid and a much higher level of $\mathrm{Ca}$ in all the structures analysed, in comparison to the control material. The content of $\mathrm{S}$ and $\mathrm{Ca}$ was typically three to four times higher in pigment (Fig. 11) and crystalloids in comparison to smooth mycelia. Droplet-like structures and crystalloids differed only in the content of $\mathrm{Cl}$ and $\mathrm{Na}$. The presence of $\mathrm{Pb}$ (up to $2.5 \%$ ) was found only in mycelia growing close to the media while it was totally absent in aerial mycelia. 


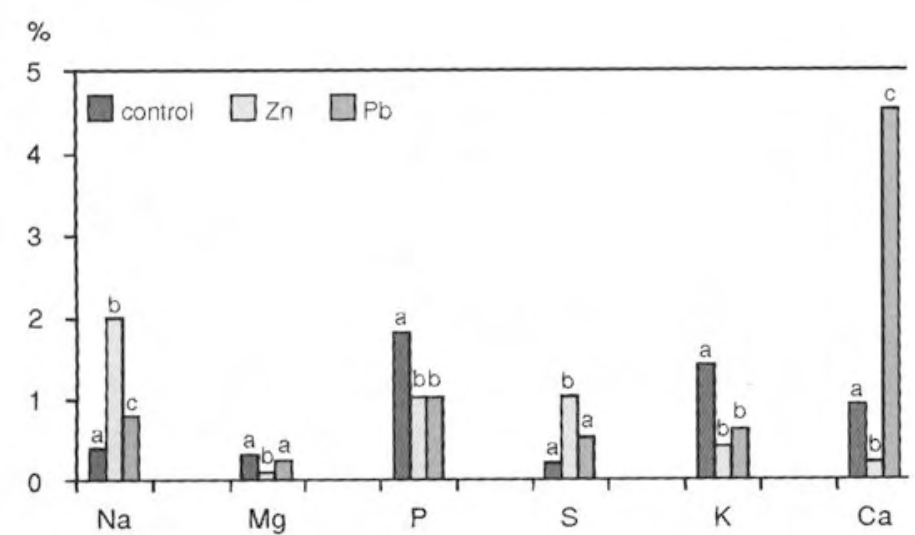

Fig. 11. Element content within droplet-like exudates on the surface of the mycelium of $R$. roseolus cultivated on MNM media with an addition of $\mathrm{Zn}, \mathrm{Pb}$, or in the pure media (control); data (in \% of dry weight) obtained by means of energy dispersion spectroscopy connected to a scanning electron microscope.

\section{DISCUSSION}

No significant growth inhibition by the presence of $\mathrm{Zn}$ in media accompanied by a change of mycelium colour of $R$ hizopogon roseolus in cultures suggests a role of the pigment in sequestration of toxic element. A similar situation has already been described in the case of saprophytic fungi (Gadd 1990). A few pigments have already been isolated from $R$. roseolus (Gill and Steglich 1987). Unfortunately nothing is known about their localization at the ultrastructural level. As it was shown before for mycorrhizas of $R$. roseolus/Pinus sylvestris, the pigment-like material deposited on the surface of extraradical mycelium and in the outer fungal mantle, plays a crucial role in heavy metal sequestration (Turnau et al. 1996). This phenomenon probably plays an important role in the colonization of polluted areas by Pinus sylvestris.

The presence of droplet-like incrustations has already been observed in the mycorrhizal fungus Rhizopogon luteolus (Uhl 1988 ) and in R. subcaerulescens (Agerer et al. 1996). According to Agerer (1987-1995) the emanating hyphae as well as the outer hyphae of the mantle can be coloured in different ways: membranaceous (cell wall pigment), epimembranaceous (pigmented material on the surface of the cell wall), vacuolar or plasmatical. In R. luteolus, Uhl (1988) described hyphae as yellowish from membranal and plasmatic pigment. In $R$. subcaerulescens emanating hyphae, the presence of extracellular drops of reddish brown pigment, as well as crystalloids have already been described (named by the authors as "crystals" but as they also illustrated these structures are rather irregular). Mycelia of $R$. roseolus displayed the presence of both structures, however, the pigment was of much paler appearance (yellowish). The hypothesis by Agerer et al. (1996) concerning the protein nature of crystalloids has been confirmed for $R$. roseolus. Our data (Gomori-Swift test) also show the similar nature of the exudate droplets. As crystalloids and droplets generally do not differ significantly in element composition, while the mycelium is cultivated without heavy metals, we suggest that they possibly differ only in age or stage of dryness.

The results described above have shown the presence of potentially toxic elements within the droplets and crystalloids on the surface of mycelia, cultivated on agar media. Previously it was discovered in mycorrhizas collected from ca- lamine wastes where several different heavy metals were present in the mixture. The common deposition of crystalloids in surface layers of the mantle were noticed while such depositions were not found in mycorrhizas lacking a heavy metal addition, that were cultivated in the laboratory. These data point out the differences in reaction of the mycelium to metals applied in isolation. The differences in element content between smooth mycelia, pigment and crystalloids depending on the presence or absence of metal seem to be obvious. The redistribution of elements such as $\mathrm{S}$ is especially interesting. The increase in droplet-like exudates on the surface of mycelia, cultivated on $\mathrm{Zn}$ supplemented media suggests a role for such substances as cystine-rich proteins in detoxification. This was confirmed by the Gomori-Swift test. The appearance of the abundant oily material within droplets, however, would also highlight the role of this material in $\mathrm{Zn}$ sequestration. As the change of mycelium pigmentation associated with an increase of oily fraction of exudates, it is possible that this is the substance where the pigment is localized. The increase in the abundancy of this component resulted in the alteration of the element content. Unfortunately, the comparatively deep penetration of the electron beam during EDS analysis did not allow for the discrimination between layers of the exudates where cystine-polysaccharidous substance or oily material prevailed, as it is not possible to indicate which layer is more effective in heavy metal sequestration.

The presence of $\mathrm{Zn}$ in the whole mycelium with a tendency to decrease towards the top of the aerial mycelia indicates the movement of $\mathrm{Zn}$ within the surface layer of the mycelium wall (apoplast). As the $\mathrm{Zn}$ content is rather high it is not expected that symplastic transport could be the main pathway and that $\mathrm{Zn}$ was subsequently exudated. Exudates would rather represent a sort of barrier where $\mathrm{Zn}$ could again be chelated, perhaps more strongly than within the polysaccharidous layer. Analysis of the same material, using TEM in connection with electron energy loss spectroscopy (unpublished material), has shown that after chemical fixation, including organic solvent, hardly any $\mathrm{Zn}$ is left in the polysaccharidous layer, while it is still possible to find $\mathrm{Zn}$ within droplet-like exudates. The removal of $\mathrm{Zn}$ during TEM preparation was the reason for applying SEM with the EDS method on freezedried material. The Gomori-Swift test, revealing the presence of cystein rich proteins or peptides as well as the increase of S shown by the EDS studies, might also suggest the presence of hydrophobins (Talbot 1997). Hydrophobins are common substances in fungi and are formed in aerial mycelia where they serve as glue between hyphae. They are believed to play an important role in the differentiation and aggregation of the hyphae.

The $\mathrm{Pb}$ distribution in mycelia of $R$. roseolus has shown a completely different pattern than $\mathrm{Zn}$. It seems to be chelated in places of direct contact and not transferred by the fungal apoplast. Also the increase of $\mathrm{Ca}$ content in the pigment suggests a strong alteration of the exudates, perhaps in the direction of organic acid production which could be used for $\mathrm{Pb}$ chelation.

\section{ACKNOWLEDGEMENTS}

We wish to thank Professor Wincenty Kilarski (Electron Microscopy Unit, Institute of Zoology of the Jagiellonian University, Kraków, Poland) for making the work with SEM and EDS possible. Special thanks are also due to Dr Olimpiusz Wenhrynowicz (Institute of Botany of the Jagiellonian University, Kraków, Poland) for his help with the PCR/RFLP verification of isolate identity. The equipment used was do- 
nated by the Polish Scientific Foundation (SUBIN 94 and REGLE 25/97). We are also indebted the Polish Committee of Scientific Research (KBN grant no. 6P04F 055 11) and the European Commission (IC20CT970002) for their financial support.

\section{LITERATURE CITED}

AGERER R., MULLER W.R., BAHNWEG G. 1996. Ectomycorrhizae of Rhizopogon subcaerulescens on Tsuga heterophylla. Nova Hedvigia $63(3-4): 397-415$.

AGERER R. (ed.) 1987-1995. Colour Atlas of Ectomycorrhizae. Schwäbisch Gmünd, FRG.

GADD G. M. 1990. Metal tolerance. In: C. Edwards (ed.), Microbiology of extreme environments. Open University Press Milton, Keynes, Oxford, Alden Press, pp. 178-218.

GARDES M., BRUNS T.D. 1991. Rapid characterization of ectomycorrhizae using RFLP pattern of their PCR amplified-ITS. Mycol Soc Newsletter 41: 14.

GILL M., STEGLICH W. 1987. Pigments of fungi (Macromycetes). In: W. Herz; G. Grisebach; W. Kirby; Ch. Tamm (eds), Fortschritte der Chemie organischer Naturstoffe. Progress in the Chemistry of Organic Natural Products. Springer Verlag, Wien, New York, pp. 1-297.

HALL J.L., HAWES C. 1991. Electron microscopy of plant cells. Academic Press, London.

KOTTKE I. 1991. Electron-energy-loss spectrometry and imaging technique for subcellular localization of elements in mycorrhizae. In:
A.K. Varma; J.R. Norris; D.J. Read (eds), Experiments with mycorrhizae. Methods in Microbiology 23: 369-382.

SAMBROCK J., FRITSCH E. F., MANIATIS T. 1989. Molecular cloning: a laboratory manual. 2nd ed. Cold Spring Harbor Laboratory, Cold Spring Harbor, N.Y.

SWIFT J.A. 1968. The electron histochemistry of cysteine-containing proteins in thin transverse sections of human hair. Journ Microscopy 88: 449-460.

TALBOT N.J. 1997. Fungal biology: Growing into the air. Curr Biol 7/2: 78-81,

THIERY J.P. 1967. Mise en evidence des polysaccharides sur coupes fines en microscopie electronique. Journ. Microscopie (Paris) 6; 987-1017.

TURNAU K., DEXHEIMER J., BOTTON B. 1995. Heavy metal sequestration and filtering effect in selected mycorrhizas from calamine dumps - EDAX microanalysis. Proceedings of 10th International Conference on Heavy Metals in the Environment Hamburg. Vol. II. 317-320.

TURNAU K., KOTTKE I., DEXHEIMER J. 1996. Toxic element filtering in Rhizopogon roseolus/Pinus sylvestris mycorrhizas collected from calamine dumps. Mycol Research 100(1): 16-22.

UHL M. 1988. Studies on ectomycorrhizae-XV. Mycorrhizae formed by Rhizopogon luteolus on Pinus silvestris. Persoonia 13(4): 4449-458.

WHITE T.J., BRUNS T., LEE S., TAYLOR J. 1990. Amplification and direct sequencing of fungal ribosomal RNA genes for phylogenetics. In: M.A. Innis; D.H. Gelfand; J.J. Sninsky; T.J. White (eds), PCR Protocols. A guide to Methods and Applications. Academic Press, San Diego, pp. 316-322.

\section{WPŁYW CYNKU I OŁOWIU NA GRZYBNIE RHIZOPOGON ROSEOLUS. BADANIA CYTOCHEMICZNE ORAZ BADANIA WYKONANE PRZY UŻYCIU MIKROSONDY ELEKTRONOWEJ EDS}

\section{STRESZCZENIE}

Grzybnia izolowana z owocników Rhizopogon roseolus, zebranych na terenie hałd galmanowych w Olkuszu, hodowana była na pożywkach agarowych z dodatkiem ołowiu i cynku. Obecność cynku stymulowała wydzielanie kropli na powierzchni grzybni powietrznej oraz na grzybni rosnącej po powierzchni agaru. Bardziej obfitemu tworzeniu się kropel wydzielin towarzyszyło ciemniejsze zabarwienie grzybni. Obecność ołowiu stymulowała natomiast tworzenie krystaloidów na powierzchni grzybni znajdującej się w bezpośrednim kontakcie z podłożem. Krople substancji wydzielane na powierzchni grzybni rosnącej na podłożu z dodatkiem lub bez soli cynku poddano badaniom za pomocą metod cytochemicznych (testy PATAg na polisacharydy oraz Gomori-Swifta na obecność białek zawierających cystynę). W materiale kontrolnym krople wydzielin cechowała pozytywna i równomierna reakcja na oba testy. Na podłożach z dodatkiem cynku, obok kropli podobnych do opisanych dla kontroli, pojawiły się obficie krople o charakterystycznym oleistym wyglądzie i reakcji negatywnej lub bardzo słabej względem obu testów. Reakcję pozytywną względem testu Gomori-Swifta stwierdzono natomiast w rejonie kołnierzykowatego brzegu wokół podstawy kropli. Badania porównawcze nad składem wydzielin grzybni hodowanej na podłożach z dodatkiem i bez metali ciężkich przeprowadzono przy zastosowaniu mikroskopu skaningowego i techniki EDS. Wykazały one istotne różnice w zawartości siarki, potasu, fosforu, wapnia i magnezu w zależności od zastosowanego metalu ciężkiego.

SŁOWA KLUCZOWE: ektomikoryza, Rhizopogon roseolus, detoksyfikacja metali ciężkich, barwniki. 